\title{
ImAgeleSS IN ANgola - ApPropriating Photography
}

\author{
Afonso Dias Ramos
}

One of the most bizarre aspects of the war in Angola is that hardly anyone has seen it. Michael Kaufman (I975) ${ }^{\mathrm{I}}$

A hundred thousand people dying in Quito of starvation because they can't get out of the city, and no one's got pictures. Well, damn! This is important! Stephen Dupont (I993)

I'M HERE IN THE MIDDLE OF WAR AND CHOLERA, STRUGGLING TO MAKE A FILM, DO ANY OF YOU CARE? OR HAS ENGLAND CEASED TO EXIST? ANGOLA IS PART OF THE WORLD YOU KNOW.

Toni Strasburg $(2009)^{3}$

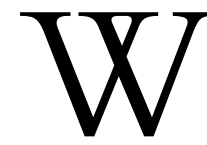

hy is it that among the photographs scorched into the pages of modern history nearly all the deadliest wars from the latter half of the twentieth century are missing? Despite the marked increase in publications on conflict photography about this period, the discourse overwhelmingly hinges on a limited roster of historical events (Bosnia, Iraq, Israel, Rwanda or Vietnam), with barely a trace of the world's largest conflicts. Politics and media are often denounced for overlooking those so-called invisible wars, but the extent to which academics also continuously fail to address them in their own fields is rarely scrutinized. As a recent literary survey concerning global history since World War II revealed, for example, some of the bloodiest conflicts (Angola, Algeria, Burundi, Congo or Ethiopia) have been systematically unacknowledged. ${ }^{4}$ Surely, it is no coincidence that the wars written out of history are also those more often 
lamented for their absence of images. How to make sense of this apparent correlation between the lack of visual salience of some conflicts and their inability to register as history?

Invented in the same century as history, as Roland Barthes noted, photography has been its accomplice in selecting what counts as reality, framing how we view and think the world. ${ }^{5}$ It was precisely to this point that the late Susan Sontag reverted in order to recant her earlier, widely influential, scepticism towards images of suffering by claiming that they must not be dismissed since war is made real because of them:

The western world knows about the horrors of Biafra, Rwanda and Sierra Leone, through the trail of catastrophic photojournalism that tracked them; Angola, however, is less real to us, as little photographic evidence escaped that conflict. $^{6}$

Sontag's argument coincided with the end of Angola's conflicts, which lasted half a century and included the longest colonial war (I96I-74) and longest civil war (1975-2002) in Africa. The wars played a central role in ending Portugal's reign as both the oldest dictatorship in Europe and colonial empire in the world, in liberating Namibia and Zimbabwe, and ending Apartheid in South Africa. In the latter half of the century, these wars were virtually unparalleled in their tolls of destruction and international implications, encompassing 'a global contest involving all of Africa, Cuba, China, the two superpowers, Europe, and most of the Third World'. ${ }^{7}$ So why is the inverse true in terms of their representation dominant historical and iconographic accounts? In an age when, as Alan Trachtenberg put it, 'historical knowledge declares its true value by its photographability,' it is as if the seeming inaccessibility to the gaze of the most dramatic contemporary events in the Atlantic robbed them of reality and historicality. ${ }^{8}$

How can forty years of warfare not yield a single image to act as an emergency imperative, nor leave behind any recognisable icon so that we may recall its tragedy? The dearth of images of Angola is often uttered. Sontag's point ends there as well, as the category of invisible functions as an alibi to prevent further investigation, probing this historical event for what it is not rather than for what it is. But a closer inspection reveals that, in fact, plenty of images escaped the conflict. The issue, far from strictly quantitative, is rather 
why those images failed to puncture public consciousness and to impinge on the outside world. What produced and sustains this enduring perception of Angola as a 'war without chronicles, without photographs, without images'?9

The postmodern focus on iconic events that organises our thinking on photography, as instanced by Sontag, dismisses these questions as secondorder reflections. Such an overreliance on readily visible conflicts has, in turn, cornered critical discourse into a dialectical impasse, wherein it is ever bound to reiterate obsessive postmodern refrains on image saturation or representational shortcomings. This theoretical gridlock has, in my view, not only entrenched hierarchies of suffering set by the skewed selectivity of media and politics, but also severely curtailed what is deemed relevant to discussions of the medium, enshrining certain historical events at the expense of rendering others irredeemably absent. The circularity of these intellectual protocols therefore plays an integral role in rendering some conflicts imageless. And by imageless, I mean the generalised perception that those wars are without images even though they do exist, being invisible to us only inasmuch as we are blind to them. To address this systemic dismissal of violence and images produced by modernity, the mediated absences must be heeded, bearing in mind that 'what does not exist is, in fact, actively produced as non-existent [...] disqualified and rendered invisible, unintelligible, or irreversibly discarded'. ${ }^{\text {Io }}$ This means rejecting any strict antagonistic relations between the visible and the invisible, so as to counter the ingrained discursive routine of 'assigning Africa to a special unreality,' as Achille Mbembe wrote, 'such that the continent becomes the very figure of what is null, abolished, and, in its essence, in opposition to what is'. ${ }^{\text {II }}$

To move beyond the vitiated postmodern verdicts, let us consider not the wars rendered exceptional by a rich lode of iconic pictures, but the neglected conflicts that are the norm, elided from the visual mainstream and positioned outside of history, and thus doomed to be read through negative interpretations. ${ }^{\mathrm{I} 2}$ Rather than discarding the issue of invisibility as a lack of images, our attention should be re-directed, following Slavoj Žižek, to that complex 'filtering mechanism' blocking an existing image 'from achieving its full impact in our symbolic space'. ${ }^{13}$ This means looking beyond issues on the public agenda and into those conflicts that 'no one dares to confront head on,' looming off the radar precisely because 'the death of a West Bank Palestinian child, not to mention an Israeli or an American, is mediatically worth thousands 
of times more than the death of a nameless Congolese'. ${ }^{14}$ Indeed, as Douglas Nickel has timely reminded us: 'The point of photography's postmodern adventure, after all, was not simply to engender self-consciousness for its own sake but to enable new histories and new theories to be erected upon methodological foundations that were more secure than those of the past. The question is thus: where are those new histories?'. . $^{\text {s }}$

This essay considers how these histories have been articulated through critical practices in contemporary art. Among the many experimental and photographic-based aesthetic strategies that emerged over the last decade in response to the inordinately vexed relation between images and political violence around Angola, I focus on that of appropriation. Given the scope of this text, I will restrict myself to analysing three artists: Daniel Barroca (Portugal, b. 1976), David Brits (South Africa, b. 1987) and António Ole (Angola, b.I95I). I argue that their works enact a mutual interrogation of history and photography that reinvests the postmodern strategy of appropriation with political potential by upending its procedure: shifting the critical focus away from the spectacle of readily visible events and the putative end of history in order to reckon visually with the histories that were marginalised by such epistemological framework.

\section{Wars that never were}

You think that I took, that one takes photographs?

One goes there, one comes back, and hush hush.

Fernando Assis Pacheco (1976) ${ }^{16}$

The artists Daniel Barroca and David Brits grew up under the traumatic hangover of their countries' wars abroad to maintain the last bastion of white rule in Africa ${ }^{17}$ - the Portuguese Colonial War in Angola, Guinea-Bissau and Mozambique (196I-75); and the South African Border War in Angola and Namibia (I966-89). Each struggles with their fathers' conscription, disturbed by how those monumental events passed down in silence. The existence of these wars, officially denied in the past, was never to be acknowledged in the future, for they landed on the wrong side of history. They were expunged from collective memory, repressed in favour of a clean slate, without any public scrutiny or legal challenge. In Portugal, the war-weary soldiers toppled the dictatorship at home turning into heroes overnight, no questions asked. 
In South Africa, the Truth and Reconciliation Commission confined itself to the country's borders, even as it made clear that the grossest human violations of the Apartheid regime occurred in Angola, 'that place beyond the pale', as David Bunn put it, "where the refinements of torture were perfected and then exported back to South Africa'. ${ }^{18}$

This wilful blindness to the events of the past (we have no detailed study on the role of the visual in the wars or compilation of their photojournalist legacy) buttressed the political effort to make them invisible through censorship and propaganda. Indeed, while the narratives and ideologies framing the conflicts in Angola vary according to opposing factions and countries, whether in Cuba, Portugal or South Africa, they were all perceived as invisible, for the covert, denied, censored nature of the involvements rendered exceedingly difficult the production and circulation of visual representations.

Deprived of easily accessible pictures, Barroca and Brits turn to the available image bank. They scavenged for residual shots in family albums, second-hand books or websites, envisaging the past through neglected found imagery: amateur snapshots which, paradoxically, form the majority of published photographs about these wars. ${ }^{19}$

In map of complicities (2O I I), Daniel Barroca sourced images of the Portuguese Colonial War from his father's war album, entirely made of snapshots bought from other soldiers, since few among them owned a camera. Barroca's work confronts the ways in which a three-front war in Africa by Europe's poorest country - 'the largest military effort of a Western country since $1945^{20}$ - has been repressed in national consciousness and visual culture, never revealing the location of the images (Guinea-Bissau) to viewers. As writer João de Melo recalls, 'everyone has a father, a brother, an uncle, or a friend who lived the damned colonial wars, and nearly all Portuguese houses hide a photo album in the bottom of a drawer. But the photos are yellowing, fading and with irreparable creases'. ${ }^{21}$ Barroca attends precisely to those private and obsolescent photographs, enlarging them and placing them on gallery walls and tables for close inspection. We see troops carousing - drinking, smoking, playing monopoly, - a mixed iconography of leisure and solace that is the fixture of this kind of imagery. The picture above portrays comrades in arms, cheerfully raising their glasses to the lens. But aside from the combat fatigues, there is no trace of war. The film, damaged over time, bears freshly carved incisions and rough lines tying the protagonists in a tight-knit web. Other 


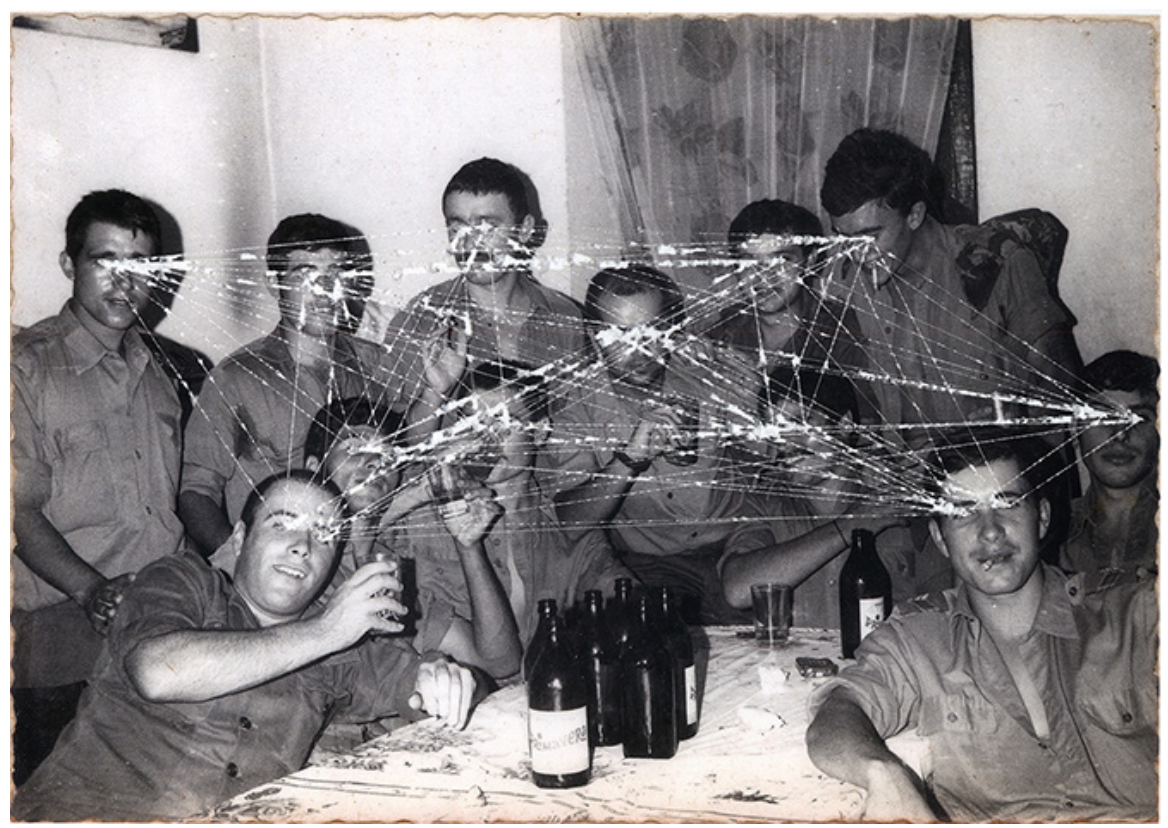

Figure I Daniel Barroca, Map of Complicities \#1, 20 I I. Scratched inkjet print, $\mathrm{IOO} \times \mathrm{I} 4 \mathrm{O} \mathrm{cm}$. Collection of the artist. (C) Courtesy of the artist. Photo: Daniel Barroca.

photographs enact similar strategies of cutting and concealment, with glasses of murky water, white powder, or blades placed over these men, needles stuck into their eyes, or else fragmenting the pictures into arbitrarily arranged pieces.

In the same year, David Brits produced SADF Facebook Series (20II). These are also pictures of conscripts in the Border War but in this case purloined by Brits from veteran groups online, which in the absence of official public fora, have allowed for images to be shared. Indeed, as Rory Bester reminds us, 'The dead remains of this era of South African history are scattered in photo albums, hidden in clothes cupboards, mostly forgotten, often forsaken'. ${ }^{22}$ The image typifies such portraits of soldiers stiffly posed alongside weaponry in a display of male bravado. But Brits' intervention mars the figure's identity. The soldier's face is blackened out with ink and scratched off violently, ripping the pigments off the paper. Similar strategies of defacement are brought to bear on the other photographs downloaded 


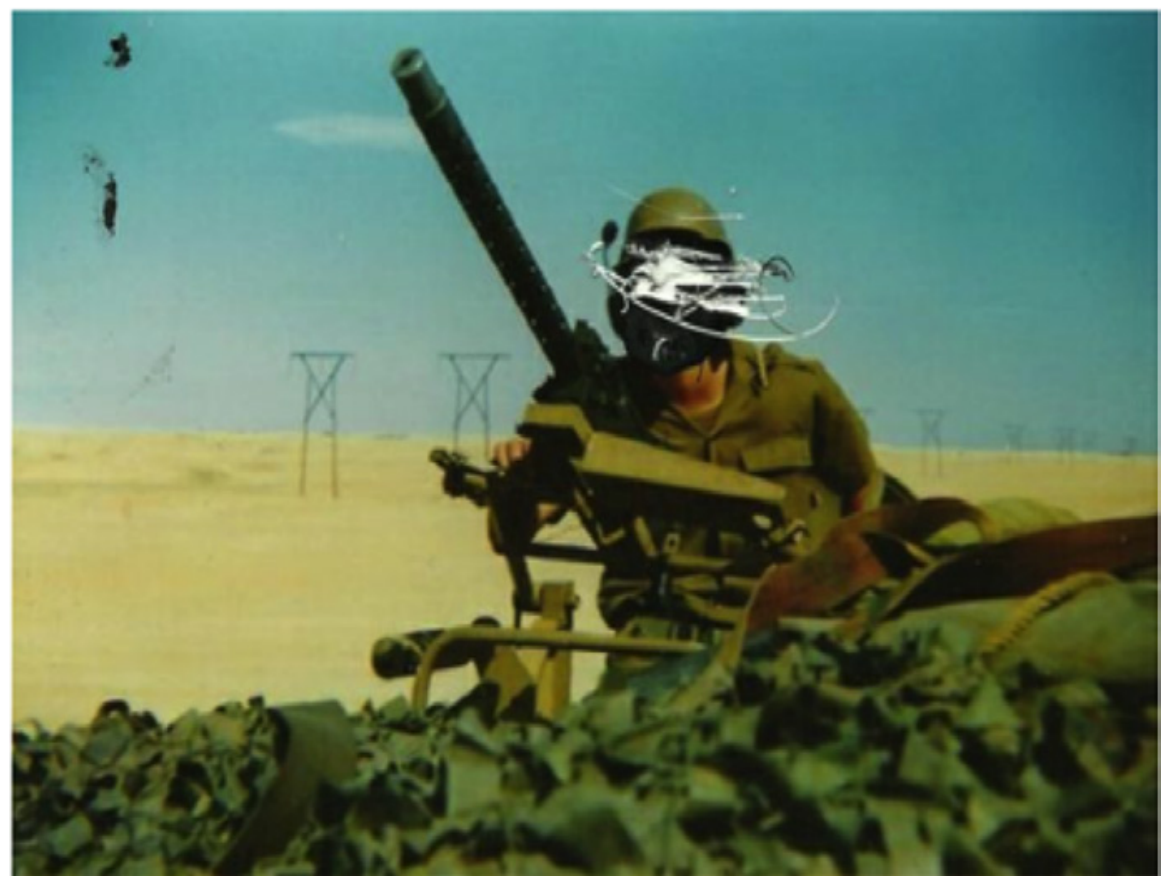

Figure 2 David Brits, Patrol I, 2011. Ink on incised Facebook photograph, I $4 \times 9 \mathrm{~cm}$. Collection of the artist. (C) Courtesy of the artist. Photo: David Brits.

for this series, whose mundane visions only show soldiers posing theatrically, playing football or swimming together.

Both Barroca and Brits disrupt the implied secrecy of the pictures intended as keepsakes to be shared among fellow troops. Opposing state policies to confined war to the domestic lens of the family rather than as public event, these artists open up the private snapshots as political. They bring the war home by literally forcing it out of it, but cognisant that the repressive mechanisms which conditioned the production and consumption of images also prescribe what lies within their frame. ${ }^{23}$ The Portuguese were not allowed to capture sensitive areas on film. South Africans faced jail if caught with a camera. ${ }^{24}$ Our vision of the events in Angola is therefore largely reliant on portraits of, by, and among friends, and even these were censored since undesirable negatives were confiscated from studios by the authorities: 'Photos were dropped at civilian central labs, and ultimately 


\section{OBJECT}

everything was censored. [...] None of the photos I took of bodies came back. I only received photos of damaged buildings and burnt-out vehicles - non-offensive and non-sensitive stuff. ${ }^{25}$ Although hard to find today, such trophy photographs did circulate, as necessary doubles to the innocuous portraits that rule our visual imagination. Barroca himself considers the most haunting aspect about his album to be one image of a black man beaten to death he found hidden behind the banal snapshots, snapping into relief such complex relays of visibility and invisibility.

Barroca and Brits face up to these unyielding visions of the past armed with knives, problematically poised as they are between participation and testimony. They vandalise the integrity of originals, which largely limited to male bonding scenes and uneventful daily rituals, codify the dominant way of talking about these wars in terms of camaraderie and masculinity, ignoring the extreme violence around it. Unwilling to disclose information on war untethered to such encrypted narratives, and compounded by rarer images from the other side, the snapshots relay an unreal sense of normalcy, bolstering the illusion that war never took place, as Portugal and South Africa stated.

The artists' mistrust of the inherited visual facts of war then leads them to turn the snapshots on their heads. They raid them for aesthetic experiments, coaxing them into something new in a relation of negotiation and disruption, as a way to displace their truncated meanings. Quite impetuously, in Brits' ferocious thrusts or Barroca's surgical rigidity, they work into the material, scratching surfaces, subtracting details, and disfiguring protagonists. On the one hand, these obstructions signify events that, banished from memory and blocked from public view, never made the historical stage. They mirror, as Brits put it, 'the feeling of being erased from some kind of national memory or narrative'. ${ }^{26}$ On the other hand, they translate the destruction brought upon the representation of history. Unable to situate the war within the visual field, their use of cancellation and opacity may trigger, paradoxically, a more complex appreciation of memory and images. As Barroca states, it is 'an attempt to empty their visibility that in the end re-enhances their visibility. It's very perverse but when it gets clear that something is disappearing it becomes more graspable'. ${ }^{27}$ In both cases, the contradictory impulse of digging up images to block them out betray an ambivalent push-pull between disclose and denial: they refuse to let events slip out to invisibility, but never will 
them into full visibility. At pains to broker an engagement with this past, they create obstacles to knowledge and vision, preventing that which is inscribed from emerging into plain view and also helping to bury this sight.

This appropriation subverts the postmodern practice of poaching photographs, often accused of ignoring history by pilfering past images simply for the purposes of modernist myth busting. This destructive modification, conversely, repurposes the original snapshots in order to turn their material dispositions toward a confrontation with history. The violence and erasure of war is turned on the images, destabilising the legibility and authority of photographs, so that they do not become a substitute, surrogate, or consolation for what is missing. Indeed, they do not mean to restore sight. Their attempt is not to remedy a war that remained foreign to the visible, locked in the mind's eye of those who fought it, unable to explode into public consciousness.

Pushed to the side of the historical stage by media, politics and academia, they were deemed wars of marginal images and images of marginalised experiences ${ }^{28}$ cast aside by more iconic events. There is, accordingly, a politics of refusing the iconicity of images in Brits' and Barroca's work: instead of canonising them as beacons of public memory, they tread the opposite way, blowing them up, and preventing the pieces from coalescing into clear pictures. This results in paradoxical self-aware images, re-engineered to cancel any vicarious or redemptive possibilities, or illusions of the return of the repressed. Yet in making the disjunction between historical reality and pictorial material available for consideration, they also refuse to give up photography's relation to the real. Instead they negotiate the bind between representation and reflexivity and force the wounds back open by literally wounding its surface without ever rendering into full legibility that which has remained inarticulable. Mindful that pictures cannot reveal the inner dynamics of historical events, they are strategically punctured. As Siegfried Kracauer stated, '[i]n order for history to present itself, the mere surface coherence of the photograph must be destroyed'. ${ }^{29}$ These shattered visual surfaces open up new meaningful possibilities for interpreting the snapshots against iconic readings. It allows us to see not what the image is of, but expresses a past experience never allowed form or meaning. Not because it is particularly evidentiary or revelatory as an iconic image, but because it facilitates a reflective encounter and enables a language with which to think 
about these issues. Used interrogatively, it makes manifest the scratches, cuts or disruptions that are the condition of viewing. This critical interpellation of images considers what has been left out from history to be as significant as what is presented; a 'symptomatic reading' that makes and finds meaning in lacunae and holes, rather than the visible. ${ }^{30}$

Mutually interrogating the medium and history, Barroca and Brits refuse to see photographs as finished objects but as conceptual, somatic, and symptomatic sites of engagement and estrangement, a relentless exploration of image matters that implies that images matter. As Bertrand Russell wrote, 'it is by this means that we become critical of images, not by some imageless memory with which we compare them'. ${ }^{31}$ The events failed to inscribe in history and became unreal, as Sontag stated, not just due to a lack of images but because, deprived of a public gaze, they live in a state of fog, doomed to a non-existence. Barroca and Brits mobilise appropriation so that the images allow us to query the structures that sustain their inefficacy. They turn perceptible the processes by which the images have failed to inscribe, inscribing onto them their own repressive practices. They make visible 'an erasure,' as Jacques Derrida has put it, 'which allows what it obliterates to be read, violently inscribing within the text that which attempted to govern it from without'. ${ }^{32}$ These critical appropriations then assert that these wars are not devoid of images but that their existence does not imply that seeing is possible. ${ }^{33} \mathrm{~A}$ more complex account of visibility is then called upon, one not opposed to but indeed founded on invisibility and blindness. ${ }^{34}$ Imagelessness, in Barroca's and Brits's work, is revealed to be tied to the sort of images used to think about the historical events, given their rhetorical roles in legislating the kinds of tales told about them, conditioning us to say certain clichés persistently, like the thought-stopping platitude that they are 'wars without images'. 35

\section{Endangered Memories}

The urgency of this artistic attempt to find new positions in confronting history through the image is evidenced by the simultaneous emergence of photography shows about these wars in Cape Town, Lisbon, Luanda or Havana, or the launch of image-gathering initiatives as the Tchiweka Association in Angola. However, the concerted efforts to keep what happened in Angola from history extended farther than Cuba, Portugal or 
South Africa. Until recently, Russia denied that I I, ooo nationals served in Angola (1975-9I). On hearing public officials reiterating this, some veterans (whose actions were unreported by the press and are omitted in their military files) felt impelled to destroy their photographs of Angola, as the only visible signs of having been there. Instead the snapshots became a powerful antidote against historical negation when the Angolan Veterans Union displayed them at the Museum of Contemporary History in Moscow (2009), in the tellingly titled exhibition Could you not have been there? ${ }^{36}$

These historical reclamations evince the vital role of photographs in proffering 'refutations snatched from a world' which political powers 'wanted to obfuscate, to leave wordless and imageless'. ${ }^{37}$ As John Liebenberg stated, 'The war was a secret. A South African secret, a US secret, a Cuban secret and a Soviet secret. This led to a fear of the camera. Photographs would reveal secrets' ${ }^{38}$ We are pressed to look, given the political attempts to keep Angola outside the purview of photography, instituting the conditions under which violence rules with impunity, and stymieing visual records to prevent the events from entering history. Only then could we be blind to history in Angola, unable to see it even as it hosted the most dramatic international twists in the last half century, as the world's largest airlifts; as settlers fled to Portugal in 1975 , the biggest assimilation of refugees in twentieth century Europe, Cuban troops flew in to fend off South African forces; an unprecedented case of south-south cooperation in response to which Kissinger planned an invasion to the Caribbean island, a likely World War III serendipitously averted by the US presidential elections. ${ }^{39}$

These recently increasing solicitations of the visible snap into relief the tensions between seeing and not seeing, destroying evidence or evidencing destruction, which lie at the heart of Angola's imagelessness. Two of the most taboo-breaking films on the wars in Portugal and South Africa both stress the unstable visuality of these events, whose continued non-recognition necessarily means an on-going erasure. In Margarida Cardoso's The Murmuring Coast (2004), a woman ceased to recognise her husband, a Portuguese Army conscript, after finding scores of classified envelopes filled with photographs of atrocities he took part in (the film uses actual trophy photographs from Angola), all later burnt by troops who, in the face of imminent defeat, erased the visual traces..$^{40}$ In the documentary $M y$ Heart of Darkness (2O I I), the South African veteran Marius van Niekerk journeyed back to Angola to get rid 
of a shoebox hidden at home, filled with his pictures as a conscript there. After visiting old battlefields with former enemies and allies, they burn all the pictures. These flames spreading over the image banks are not mere cautionary tales. They recall actual instances of visual repositories incinerated on state orders or under unknown circumstances as the military operations ended, and also evoke their inaccessible or neglected existence in the archives today. ${ }^{4 \mathrm{I}}$

Whether in envelopes secreted away, shoeboxes in attics or albums in drawers, they remind us that the war pictures of Angola we seek to see are not readily available for perusal due to strenuous efforts to keep them below the horizon of visibility even after the event. This is not a pure absence of images, but a negation enforced through a network of intersecting discourses that seize Angola from the world, decreeing it as an empty object, inaccessibly remote or forbidden as a topic: a 'structured absence'. ${ }^{22}$

In the work of both Barroca and Brits, destruction and preservation inhabit the same object, underscoring the idea that equally important to the life of images is the destruction of images. ${ }^{43}$ But in spite of their creative parallels, their works are, in fact, unknown to one another. In the last decade Angola became the subject of an extensive body of visual representation around the Atlantic, in a refutation that the past should be written off or that it lies beyond the power of images. Other artists have recently taken up appropriation to contest the self-produced pictures that the intervening states imposed on media during war, telling us that we did not need to look. Those images actively produced the unreality of Angola by blatantly denying war or sanitising it to the point of abstraction, effectively collapsing history into myth. Such artworks have further shown the invisibility of these wars to be directly tied to the kinds of image regimes they produced, shrouded by a deluge of visual clichés that render us unable to see any images at all. But what were these official images meant to screen out? No Angolan artist is more haunted by this question than António Ole, whose work has long been driven by the imperative of rendering the country's history 'more visible'. ${ }^{44}$ In Hidden Pages, Stolen Bodies (200I), an installation made when civil war neared its end, Ole peered precisely into those black holes of Angola's past where representation is so often presumed to end, to redeem the historicity of hidden events.

In order to approach neglected and disavowed aspects of the past, in a country still in the grip of a politically-sanctioned culture of fear and silence, 


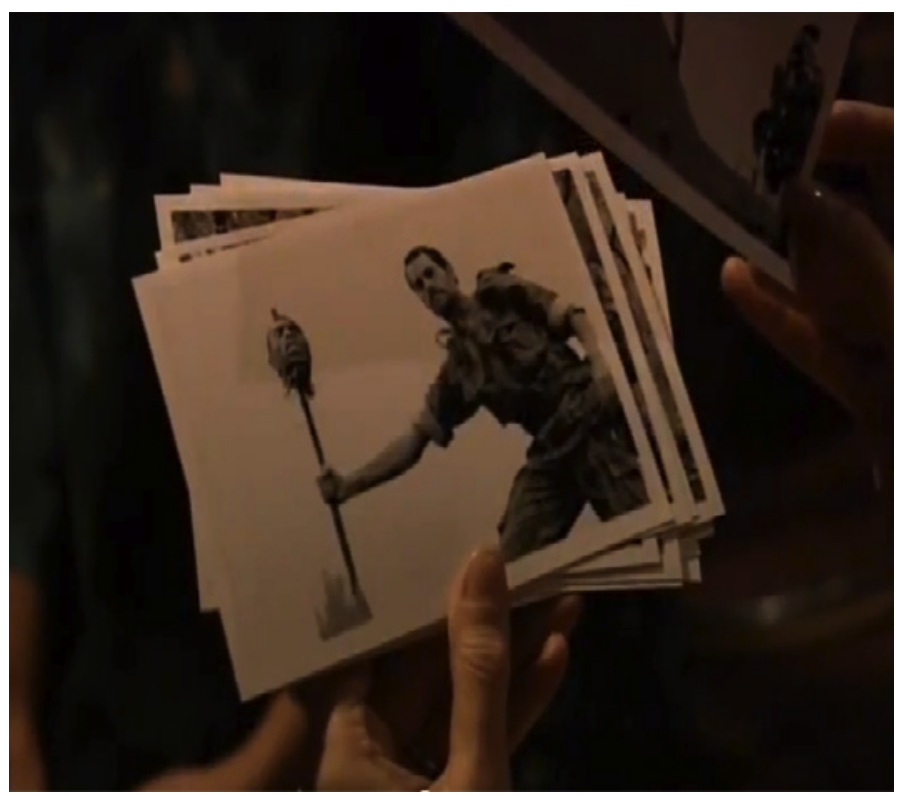

(a)

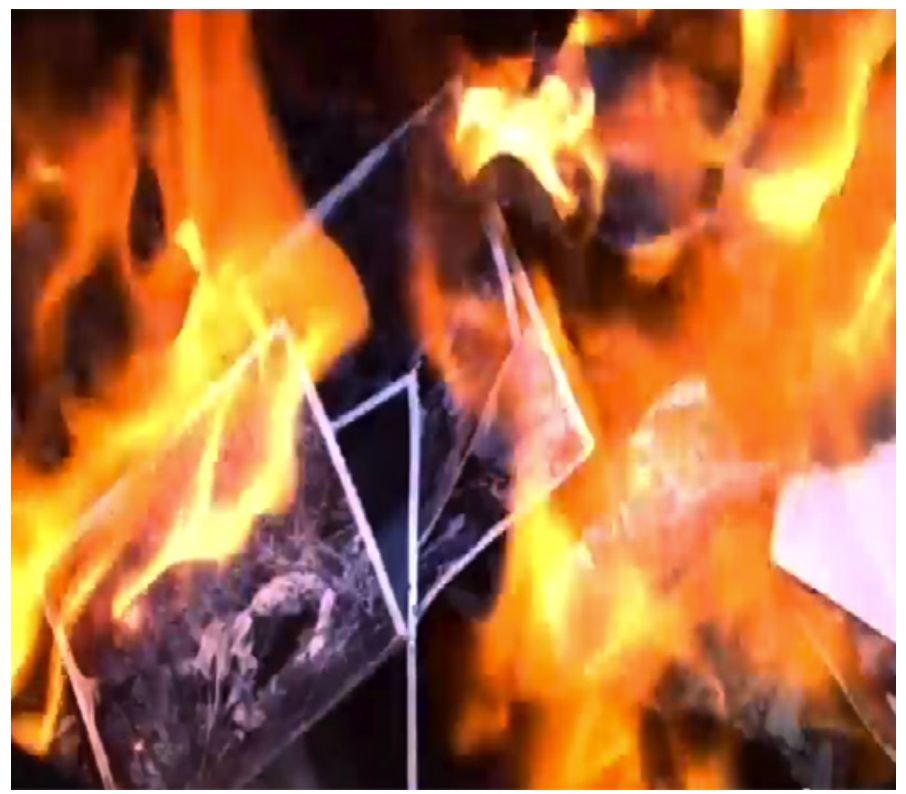

(b)

Figures $3 \mathbf{a}$ and $\mathbf{3} \mathbf{b}$ Margarida Cardoso, Stills from The Murmuring Coast, 2004. (C) Courtesy of the artist. 


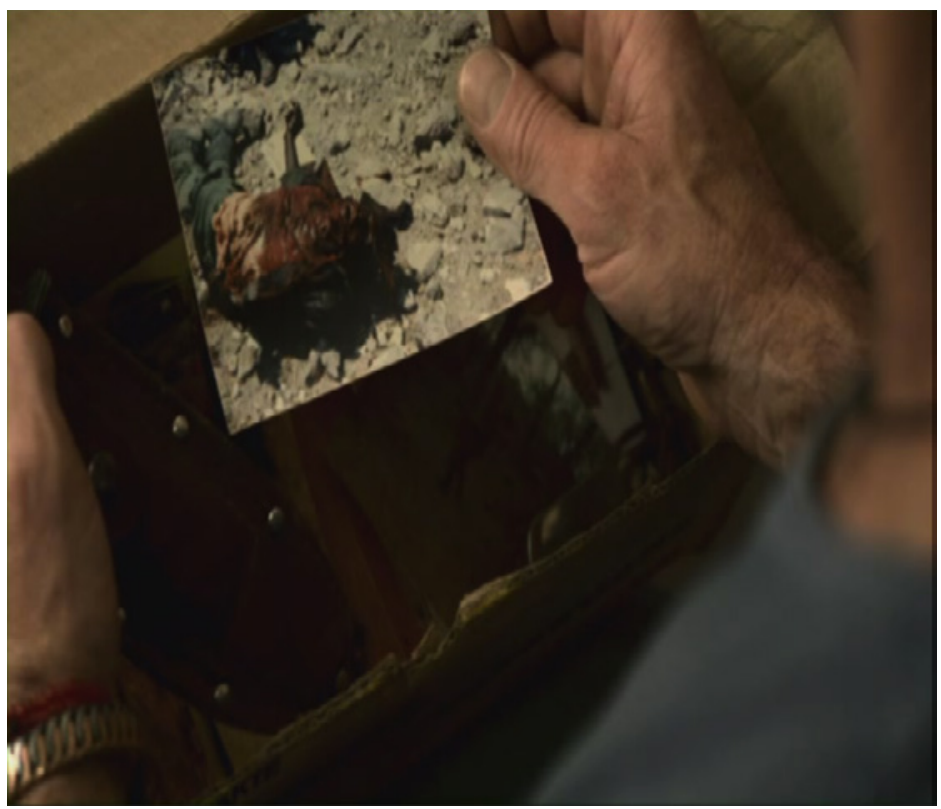

(a)

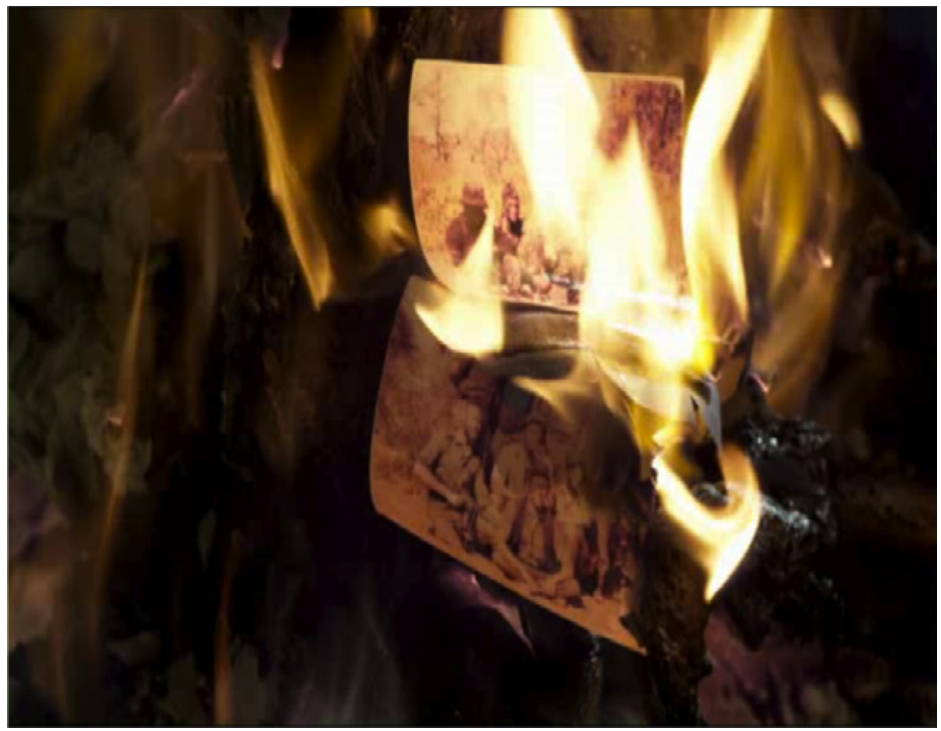

(b)

Figures $\mathbf{4} \mathbf{a}$ and $\mathbf{4} \mathbf{b}$ Staffan Julén and Marius van Niekerk (directors) and Peter Östlund (photographer), Stills from My Heart of Darkness, 20 Io. (C) Courtesy of the artists. 
Ole pivoted the installation around the biggest taboo in Angolan history: slavery and forced labour. Drawing attention to the constant atrocities over bodies in a land repeatedly wounded by violence and appropriation, this work uses those tools to consider how events of neglected historical significance may be approached. The project went through many stages over a decade. Discarding the initial idea of a film, Ole rummaged through archives in Lisbon and Luanda, culling materials and negotiating representational strategies. The final work assembles colonial newspapers, official documents, private letters, archival photographs, found objects, and a video from a prior project.

Ole's scavenging for signs of the past in order to ascertain what remains for the present is particularly urgent as Angola fast-forwards into the future as the world's fastest-growing economy in this century's first decade. ${ }^{45}$ This inebriating urge to edit and re-script history is evident in José Eduardo Agualusa's novel The Seller of Pasts (2005), the story of a man eking out a living by selling fake pasts. Catering to the affluent sectors of society craving for nobler versions of the past, this fabricator invents photographs and family trees. Instead of wishing the past away, Ole operates conversely, declining temptations to contrive alternative versions of yesterday. He re-members the dismembered past, joining remainders and reminders of a past that does not pass, so that the country turns the pages of a painful history, but not by hiding nor burning them, lest they repeat themselves in the future.

Scattered across museum walls, the vast assembly of bric-a-brac requires prolonged engagement. At close proximity, viewers realise that these are all material traces of slavery, forced labour, colonialism and both the liberation and the civil war. The work presents a chaotic view of history refusing to pigeonhole the past into neat layers or separate events but forcing viewers to read contemporary developments in the light of deeper and more complex histories. A 'permanent violence,' as Ole calls it. Indeed, in four centuries of colonial rule, 'rarely did a year pass' without a military campaign. ${ }^{6}{ }^{6}$

The peculiar historicity of Ole's installation reminds us that Angola cannot be perceived in linear ways. It revels in continuities and multiple temporalities that must be framed globally, for its missing pages are those of a country's brutal inclusion into the world economy as the longest lasting European colony and the biggest supplier of slaves in Africa, later to culminate in the longest period of war in the modern era. The viewers are then enjoined to face these hidden pages of Angolan history at a close range, in the flesh, 


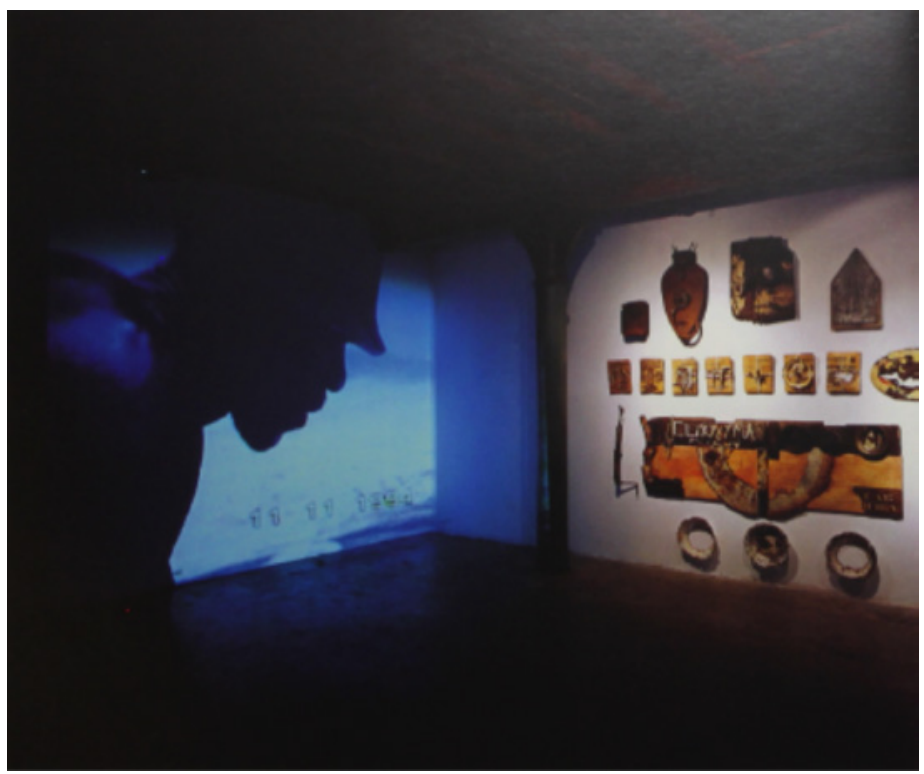

(a)

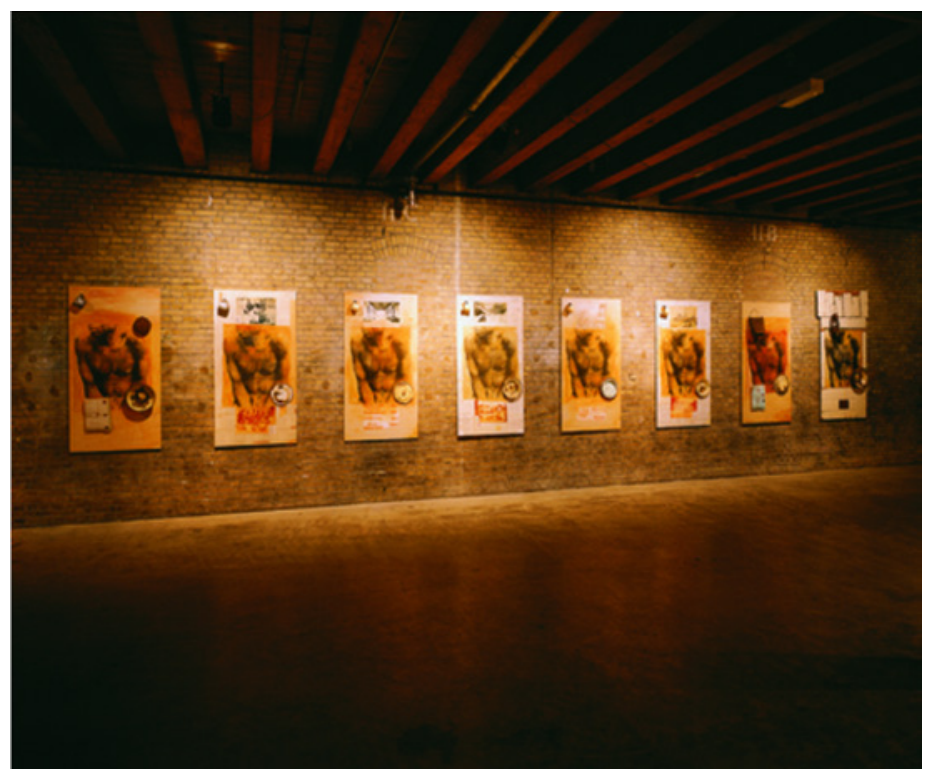

(b)

Figures 5a and 5b António Ole, Hidden Pages, Stolen Bodies, Mixed media installation, 200 I. Collection of the artist. (C) Courtesy of the artist. Photo: Gert J. van Rooij. 
confronting the material persistence of the past, as opposed to overarching abstractions which systematically rip these pages away from the annals.

The installation is organised around eight panels. Each of them bears a large reproduction of the same grainy black-and-white photograph of a slumped body, his hands bound together: a forced labourer. The clusters of found objects encircling the images include nondescript debris, animal bones, rusty dishes and scraps of documents. Ole stumbled upon this image, taken by a Portuguese photographer in the early I900s, on a postcard while perusing through the archives of Benguela, the greatest pole of slave traffic in Angola. He photocopied and enlarged it, extracting this figure from the dehumanising context of the colonial postcard, defacing it to maintain the anonymity of the individual. Going back through history in search of bodies that lost their names, and whose brutal experiences left no documents behind, this appropriation militates against the invisibility to which imperial discourse renders black Africans, forcibly removed from the world by being made invisible to it.

Ole sets up a powerful historical presence by brushing the image against the grain, usurping the postcard to identify specific individuals rather than the generic colonial stereotypes that position them outside history. The naked body that usually plays a supporting role in established accounts of the past is spotlighted on the stage. But to reiterate images that dropped out of sight, buried away in archives, is not enough to ensure the public visibility of subjects deprived of access to representation. In order to investigate what allows us to apprehend these bodies, Ole revisits the ways in which they have been framed. Along with the images, we find piles of colonial newspapers. But viewers are denied access. They are sealed with strings, bones and detritus, hints that we shall not find in these pages traces of lives that could never rely on the media.

The viewer is, in any case, allowed to read the bureaucratic and police documents spanning from the slavery years to the civil war. Although unintended for public eyes, these documents narrate the countless tales of repression and violence in past decades. Only, and crucially, they are not copies but originals, largely in shreds. Many of these papers were not archived after Angola's independence but thrown out onto the streets or ended up there as war destroyed national infrastructures. Some documents were bought by Ole from street vendors using them to wrap fruit. This appropriation of materials 

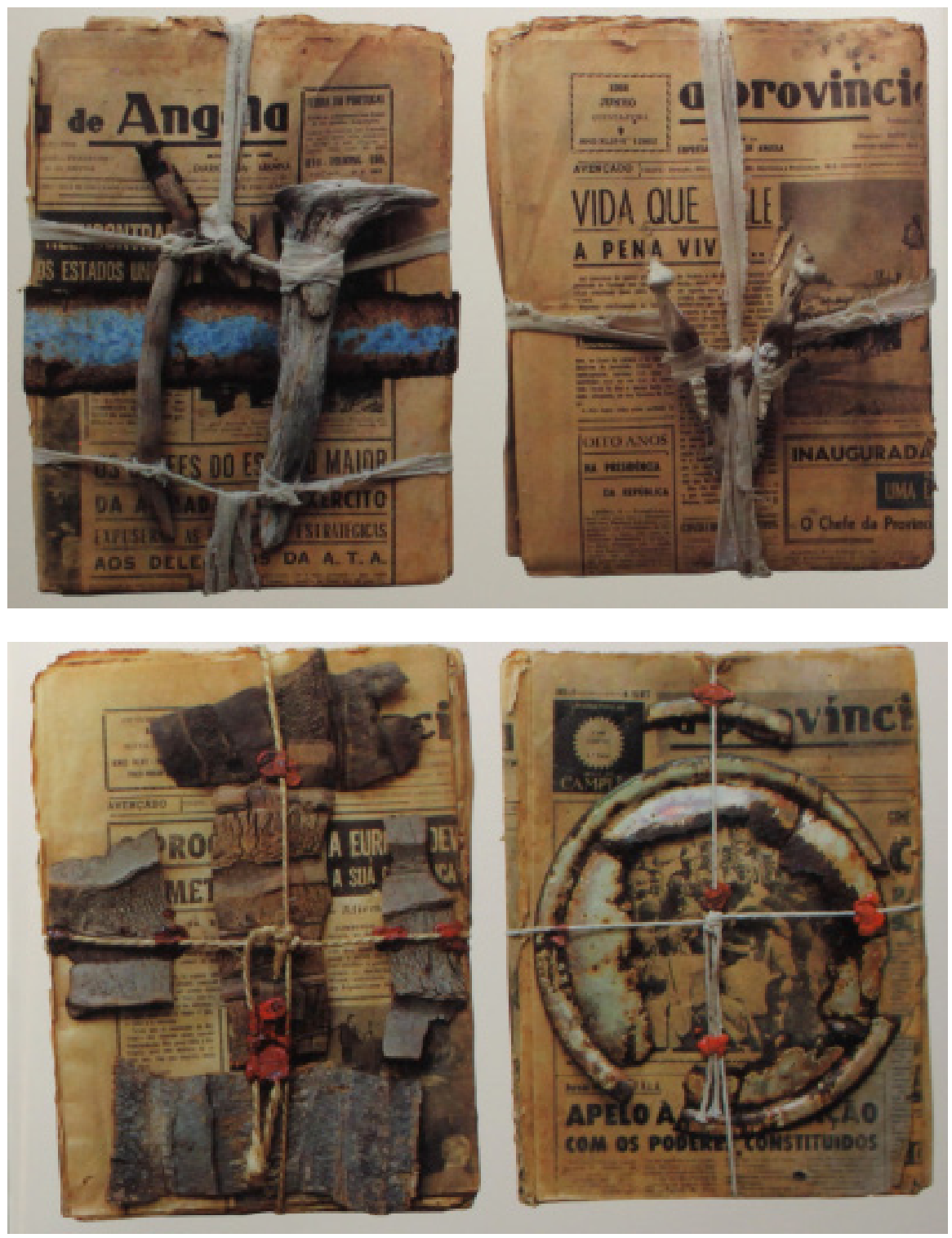

Figure 6 António Ole, Hidden Pages, Stolen Bodies, Mixed media installation, 200 I. Collection of the artist. (C) Courtesy of the artist. Photo: Gert J. van Rooij. 


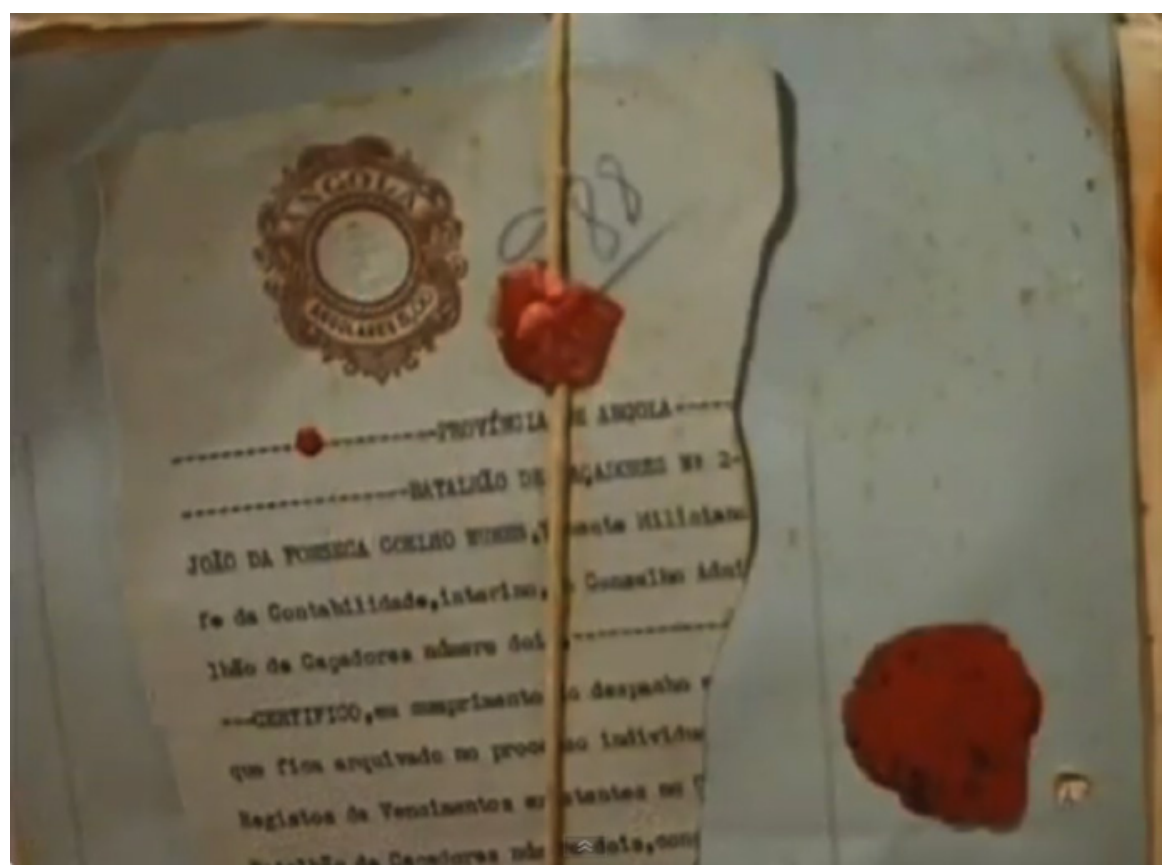

Figure 7 António Ole, Hidden Pages, Stolen Bodies, Mixed media installation, 200 I. Collection of the artist. (C) Courtesy of the artist. Photo: Gert J. van Rooij.

left by the wayside and in a fragmentary state signals the irretrievable loss of historical records, and the impossibility of a definitive account of the past.

These leftovers are not enough to deal with suppressed lives, since the material facts of history as it has been told disenfranchise them. Ole is forced to go beyond the inherited visual or verbal documentation to look for new ways of historical reckoning not bound to colonial modes of knowledge. In order to compensate for, and navigate through the absences, Ole resorts to material culture. In addition to images lost from view he also incorporates objects lost to oblivion. These are derelict and discarded objects - bones, plates, glasses, and all sorts of rusty and forsaken matters that wash up on the Luanda shore. Appended to the forced labourer, they not only make us remember the lives that once animated these remnants but also allegorise their expendable existences, trading the abstractions of a disembodied history that excludes them for the experiential realities of a past that refuses to be severed from the present. Spanning different times and events, Ole's 
installation then prevents us from placing these ravages safely into the distant past and redefines the habits of representation. Musing on the difficulties of apprehending history in Angola, Ole investigates how far context might have to go in order to grasp the symbiotic relation between endemic violence and chronic invisibility that, far from happenstance, is actively produced by the systems of power and profit that benefit from it. Ole not only brings the quest for emancipation of black subjects back into a universal narrative that excluded them but also counters the disavowals in recent accounts of the past which tell only the white side of the story, overlooking those who bore and still bear the brunt of this violence.

\section{Conclusion}

Angola is strangely conservative when it comes to photography. Mike Stead and Sean Rorison (2009) ${ }^{47}$

Months after Susan Sontag singled out this African country as the extreme case of a war made unreal to the outside world by way of image deprivation, the police issued a statement in Angola. ${ }^{8}$ So entrenched were the prohibitions against cameras during war that, shortly after the ceasefire, the authorities were informed that photography was 'not a crime' and should henceforth be tolerated. Complaints against police forces that forbid picture taking still abound today. ${ }^{49}$ Yet, in the last decade Angola has been the object of a vast body of visual representation, reversing the iconophobia that separated it from external eyes. As these artists charge back into the past, they endeavor to flip the ways in which we think and view recent history, mobilising photography's unique abilities to contest and reflect on the forces of erasure that lead to voids and amnesia.

As the latter half of the twentieth century began, Theodor Adorno stated: 'The coming extinction of art is prefigured in the increasing impossibility of representing historical events'. ${ }^{\text {so }}$ And more than any other artistic form, postmodern appropriations of images were later to be identified by critics as that very 'symptom of the waning of our historicity'. ${ }^{\text {I }}$ However, as Jan Verwoert remarked, this postmodern obsession, in aesthetic theory and practice, with empty signifiers and defunct history soon came to 'sound like a mantra, a spell to keep away the spectres of modern history that linger 
on the margins of historical discourse'. ${ }^{2}$ In reckoning what dominant epistemologies and historiographical templates rendered invisible in the way we think about the last half century (as missing images and absent histories) the artists discussed here bring to the fore precisely those critical sites which are left out of teleology and no one sees, reminding us they are neither post-historical nor anti-aesthetic. Whereas postmodern appropriations were haunted by a theological and philosophical orthodoxy that history is lost in sight, the artists reposition us instead in relation to histories we lost sight of.

If the postmodern approach to photography ran out of critical steam, overdeveloping our capacity to show that images always fail to accomplish what they set out to do, these appropriations perform a materialist approach which reinvests the medium with political potential. Shifting away from iconic historical conflicts into those left outside representation the work discussed here stress that images still manage to say something after all. Rather than unmasking the arbitrary constructedness of representations for its own sake, these appropriations discussed here mobilise and redirect the self-reflexive strategies to urge us to find meaning precisely in the fragmentary lacunae. They institute a mode of recognition about these historical events that may in turn lead to cognition, so that we might overcome our blindness and become more attentive to that which is all too readily deemed invisible, and thus pushed beyond the domain of possible knowledge.

\section{Notes}

I am immensely grateful to my supervisors, Tamar Garb and Stephanie Schwartz, for their insightful advice and help. Funding for this project was generously provided by the History of Art Department at UCL. Finally, I would like to thank Daniel Barroca, David Brits, Margarida Cardoso, Marius van Niekerk, and António Ole for providing image permissions.

I Michael Kaufman, 'Sights and Sound of War Prove Elusive in Angola', New York Times, 3 I December I975.

2 Cited in Michelle Bogre, Photography as Activism, Oxford, Elsevier, 20 I I, p. I22.

3 Toni Strasburg, Fractured Lives, Cape Town, Modjaji Books, 2009, p. I 44.

4 Virgil Hawkins, Stealth Conflicts, Aldershot, Ashgate, 2008, p. I Iо.

5 Roland Barthes, Camera Lucida, New York, Hill and Wang, I98 I.

6 Andrew Nelson, 'War Photography', 2002. http://spot.hcponline.org/pages/war_ photography_90I.asp (Accessed 7 September 2013) 
7 William James, A Political History of the Civil War in Angola, New Brunswick, Transaction, I992, p. 59.

8 Alan Trachtenberg, 'Albums of War: On Reading Civil War Photographs' in Representations, no. 9, Winter 1985 , p. I.

9 Américo de Carvalho, Angola: Anos de Esperança, Coimbra, Minerva, 200 I, p. I 26.

Io Boaventura de Sousa Santos, The Rise of the Global Left, London, Routledge, 2006, pp. I $5-16$.

I I Achille Mbembe, On the Postcolony, Berkeley, University of California Press, 200 I, p. 4.

I2 'Congo, like Angola, is the norm. Darfur is the exception.' Mahmood Mamdani, Saviours and Survivors, Cape Town, HSRC Press, 2009, p. 2 I.

I3 Slavoj Žižek, Violence, London, Profile, 2009, p. 2.

I4 Ibid., p. 3 .

I5 Douglas Nickel, 'Peter Henry Emerson: The Mechanics of Seeing', in The Meaning of Photography, Robin Kelsey and Blake Stimson (eds.), Williamstown, Clark Art Institute, 2008, p. 59.

I6 Fernando Assis Pacheco, Catalabanza, Quilolo e Volta, Coimbra, Centelha, I976, p. 48.

I7 The extent of the secret political, military and economic alliance between Portugal, Rhodesia, and South Africa, formalised in I970, was only recently uncovered.

I 8 David Bunn, 'Thoughts on a Phantom Limb', in Gavin Younge, Prosthesis, Paris, 2007, p. 32 .

I9 Photographic surveys of war rely essentially on private snapshots. Renato Monteiro and Luis Farinha (eds.), Guerra Colonial: Fotobiografia, Lisboa, Dom Quixote, I990; Cameron Blake, Troepie Snapshots, Johannesburg, $30^{\circ}$ South, 201 I.

20 Rui Ramos et al, História de Portugal, Lisboa, Esfera dos Livros, 2009, p. 680.

2 I João de Melo, 'Nós, os da geração da guerra colonial', Republica de las Letras, no. 2o, I988, p. 43 .

22 Rory Bester, 'Tracing a War', in Nka,, no . 9, I998, p. 64.

23 In Cuba, likewise, 'The vision of Angola [. . . ] survives mainly in portraits of friends and combatants.' Nahela Hechavarría, 'Angola: El archivo personal', in Anuario de Fotografia Cubana, May 2005, p. 74.

24 On Io January 1962, the Portuguese Armed Forces notified media outlets: 'It is expressly forbidden to broadcast photographs or films involving military topics without prior sanction by the military authorities.' Vasco Teves, História da Televisão em Portugal, Lisboa, TV Guia, I998, p. I I4. The South African Defence Act declared: 'No person shall unless authorized thereto by the Minister [. . ] take any photograph [. . . or have in his possession in any area so defined any camera or other apparatus which may be used for the taking of photographs.' Troepie Snapshots, op. cit., p. 22.

25 Troepie Snapshots, op. cit., p. 8.

26 Private communication with the author, I7 March 2014.

27 'The Intensity of Silence', 29 September 20I2. http://shareproart.net/2012/09/29/theintensity-of-silence/ (Accessed 2I September 2013).

28 Robert Hariman and John Louis Lucaites, No Caption Needed, Chicago, University Of Chicago Press, 2007.

29 Siegfried Kracauer, 'Photography', Critical Inquiry, Spring I993, p. 427.

30 Louis Althusser and Étienne Balibar, Reading Capital, London, I970. 
3 I Bertrand Russell, The Analysis of Mind, London, NLB, I92 I, p. 89.

32 Jacques Derrida, Positions, Chicago, University of Chicago Press, I98 I, p. 6.

33 José Gil, Portugal, Hoje, Lisboa, Relógio d'Água, 2004.

34 James Elkins, The Object Stares Back, New York, Simon \& Schuster, 1996.

35 Michael Ann Holly, Past Looking, Ithaca, Cornell University Press, I996.

36 'They were [in Angola], but their papers said they'd never left their navy base in Russia. When they found out, they were asking each other if they should just throw out the photos of them under the African palm trees.' Andrei Polikanov, 'Medvedev looking for diamonds in the rough in Angola', in RT, 26 June 2009.

37 Georges Didi-Huberman, Images in Spite of All, Chicago, University of Chicago Press, 2008 , p. 56.

38 John Liebenberg, 'No pictures please!', 20 I I, unpublished, courtesy of the author.

39 Kissinger's plan (publically released in 20I4) anticipated the invasion to lead to a conflict with the USSR. William LeoGrande and Peter Kornbluh, Back Channel to Cuba, Chapel Hill, University of North Carolina Press, 20 I 4.

40 An adaptation of Lídia Jorge's novel A Costa dos Murmúrios (I988).

4I In Quatro Países Libertados (Lisboa, Bertrand, I975), Paulo Rodrigues reproduced images from a Portuguese Army archive that burnt down during decolonisation. Cameron Blake also printed slides of Angola from SADF, though '[d]uring the I994 political and military transition the slides were ordered to be incinerated.' Troepie Snapshots, op. cit., p. 8.

42 Louis Althusser, Lenin and Philosophy and Other Essays, New York, Monthly Review Press, I97I.

43 W.J.T. Mitchell, Cloning Terror, Chicago, University of Chicago Press, 20 I I.

44 António Ole, Luanda, Banco Espírito Santo de Angola, 2007, p. 34.

45 Ernst \& Young, Angola: More than an Oil and Gas Story, 20 3.

46 Douglas Wheeler, 'The Portuguese Army in Angola', in Journal of Modern African Studies, no. 7, I969, p. 428.

47 Mike Stead and Sean Rorison, Angola, Chalfont, Bradt, 2009, p. I03.

48 Polícia Nacional de Angola, 'Tiragem de fotografias na via pública,' I I/06/05.05/ DNOP/oo3, 5 November 2003.

49 Angola's Association of Image Reporters protested against this in 2013. 'Repórteres fotográficos queixam-se da polícia', in Voz da América, I7 February 2013.

50 Theodor Adorno, Minima Moralia, London, Verso, I978, p. I43.

5 I Frederic Jameson, Postmodernism, or, the Cultural Logic of Late Capitalism, London, Verso, I99I, p. I9.

52 Jan Verwoert, 'Apropos Appropriation: Why Stealing Images Today Feels Different', in Beatrix Ruf and Clarrie Wallis (eds.), Tate Triennial 2006, London, Tate Publishing, 2006, p. I4. 